\title{
A technique for the measurement of organic aerosol hygroscopicity, oxidation level, and volatility distributions
}

\author{
Kerrigan P. Cain ${ }^{1}$ and Spyros N. Pandis ${ }^{1,2,3}$ \\ ${ }^{1}$ Department of Chemical Engineering, Carnegie Mellon University, Pittsburgh, USA \\ ${ }^{2}$ Institute of Chemical Engineering Sciences, ICE-HT, Patras, Greece \\ ${ }^{3}$ Department of Chemical Engineering, University of Patras, Patras, Greece
}

Correspondence: Spyros N. Pandis (spyros@andrew.cmu.edu)

Received: 23 June 2017 - Discussion started: 28 July 2017

Revised: 3 November 2017 - Accepted: 6 November 2017 - Published: 13 December 2017

\begin{abstract}
Hygroscopicity, oxidation level, and volatility are three crucial properties of organic pollutants. This study assesses the feasibility of a novel measurement and analysis technique to determine these properties and establish their relationship. The proposed experimental setup utilizes a cloud condensation nuclei (CCN) counter to quantify hygroscopic activity, an aerosol mass spectrometer to measure the oxidation level, and a thermodenuder to evaluate the volatility. The setup was first tested with secondary organic aerosol (SOA) formed from the ozonolysis of $\alpha$-pinene. The results of the first experiments indicated that, for this system, the less volatile SOA contained species that had on average lower $\mathrm{O}: \mathrm{C}$ ratios and hygroscopicities. In this SOA system, both low- and high-volatility components can have comparable oxidation levels and hygroscopicities. The method developed here can be used to provide valuable insights about the relationships among organic aerosol hygroscopicity, oxidation level, and volatility.
\end{abstract}

\section{Introduction}

Anthropogenic activities, such as fuel combustion, as well as biogenic sources, such as emissions from vegetation, can introduce particles and particle precursors into the atmosphere. These airborne particles have been identified as a factor contributing to cardiovascular and respiratory diseases (Pope, 2000; van Eeden et al., 2005) and an increased risk for acute morbidity and mortality (Brook et al., 2010). In addition, atmospheric aerosols influence the Earth's radiation balance directly by scattering and absorbing solar radiation and in- directly by serving as cloud condensation nuclei $(\mathrm{CCN})$. Despite their major role in the Earth's energy balance, their net effect on climate is one of the major uncertainties in the climate change problem (IPCC, 2013).

In most areas, organic compounds represent anywhere from 20 to $90 \%$ of the submicron aerosol mass (Murphy et al., 2006; Zhang et al., 2007). Organic aerosol (OA) is traditionally classified either as primary (POA) or secondary (SOA). POA refers to organic compounds that are emitted to the atmosphere directly in the particulate phase. SOA refers to particulate matter produced by gas-to-particle conversion processes. In general, intermediate-volatility, semi-volatile, and volatile organic compounds undergo oxidation in the atmosphere and form products that can produce new particles and condense on pre-existing particles.

Three of the most important properties regarding OA lifetime in the atmosphere are hygroscopicity, oxidation level, and volatility. Hygroscopicity - often quantified by the hygroscopicity parameter, $\kappa$ (Petters and Kreidenweis, 2007) is a measure of the volume of water associated with a unit volume of solute. Oxidation level often provides an indication of the age of the OA in the atmosphere. It is expressed as the oxygen-to-carbon $(\mathrm{O}: \mathrm{C})$ ratio or, more accurately, the average carbon oxidation state $\left(\mathrm{OS}_{\mathrm{C}}\right)$. Volatility determines the partitioning of organic compounds between the gas and particle phases. The one-dimensional volatility basis set (1DVBS; Donahue et al., 2006) has been proposed as a framework for the description of the evolution of the OA volatility distribution using logarithmically spaced bins.

Several studies have shown that SOA from the ozonolysis of $\alpha$-pinene is reasonable CCN material (VanReken et al., 
2005; Huff Hartz et al., 2005; Prenni et al., 2007; King et al., 2007, 2009; Engelhart et al., 2008; Wex et al., 2009; Massoli et al., 2010; Kuwata et al., 2011; Frosch et al., 2011). These studies all reported similar $\kappa$ values based on measurements at supersaturated conditions, ranging from 0.07 to 0.15 . HuffHartz et al. (2005) found that SOA produced from monoterpenes was more hygroscopic than SOA from sesquiterpenes. Both King et al. (2007) and Kuwata et al. (2011) observed that the CCN behavior of $\alpha$-pinene ozonolysis SOA was dependent on the OA mass concentration. Frosch et al. (2011) found that $\kappa$ for $\alpha$-pinene ozonolysis SOA increased with chemical aging.

Hygroscopic properties of $\alpha$-pinene ozonolysis SOA have also been studied using subsaturated conditions (Prenni et al., 2007; Wex et al., 2009; Poulain et al., 2010; Massoli et al., 2010; Tritscher et al., 2011). These studies determined a hygroscopic growth factor (HGF) to estimate $\kappa$, reporting values from 0.01 to 0.08. Massoli et al. (2010) used both a hygroscopic tandem differential mobility analyzer (H-TDMA) and a CCN counter while studying SOA from the ozonolysis of $\alpha$-pinene and found that the $\kappa$ at subsaturated conditions (estimated from HGF measurements) was $20-50 \%$ lower than that based on $\mathrm{CCN}$ measurements at supersaturated conditions. A number of explanations have been proposed for this behavior, such as increasing dissolution of SOA components at supersaturated conditions and surface tension effects (Petters et al., 2009; Good et al., 2010).

The oxidation level of $\alpha$-pinene ozonolysis SOA has mainly been studied through the use of high-resolution mass spectrometry (Bahreini et al., 2005; Alfarra et al., 2006; Song et al., 2007; Shilling et al., 2009; Huffman et al., 2009; Poulain et al., 2010; Massoli et al., 2010; Kuwata et al., 2011; Tritscher et al., 2011; Frosch et al., 2011). These studies reported $\mathrm{O}: \mathrm{C}$ ratios from around $0.3-1$. The higher $\mathrm{O}: \mathrm{C}$ ratios were determined by Massoli et al. (2010) for extended periods of chemical aging; most of the average $\mathrm{O}: \mathrm{C}$ ratios ranged from 0.3 to 0.5 . The use of the $\mathrm{O}: \mathrm{C}$ ratio can allow for easier classification of OA into different classes using the two-dimensional volatility basis set (2D-VBS; Donahue et al., 2011). Poulain et al. (2010) observed that the most oxygenated compounds were less volatile than the less oxygenated ones, and Kuwata et al. (2011) found that the O:C ratio for $\alpha$-pinene ozonolysis SOA depended on the mass concentration.

In addition to hygroscopicity and oxidation level, there have been a number of studies focusing on the volatility of SOA from the ozonolysis of $\alpha$-pinene with either a thermodenuder (TD; An et al., 2007; Kostenidou et al., 2009; Huffman et al., 2009; Poulain et al., 2010; Lee et al., 2011; Cappa and Wilson, 2011; Kuwata et al., 2011) or a volatility tandem differential mobility analyzer (V-TDMA; Stanier et al., 2007; Jonsson et al., 2007; Tritscher et al., 2011). The difficulty in comparing these volatility studies stems from different heating methods (TD, V-TDMA, etc.), residence times in heating sections, and temperatures. For example, Poulain et al. (2010) observed nearly all of the SOA evaporated at $200^{\circ} \mathrm{C}$ at a residence time of $9 \mathrm{~s}$ in the heating section of a TD, but Lee et al. (2011) reported that most of the SOA evaporated at around $90^{\circ} \mathrm{C}$ for a residence time of $16 \mathrm{~s}$. The use of the 1D-VBS (Donahue et al., 2006) can help overcome this obstacle, making it easier to compare volatility distributions rather than thermograms, which express the mass fraction remaining (MFR) as a function of temperature and are influenced by several different experimental factors (particle size, residence time in heating section, OA concentration, etc.; Cappa, 2010; Riipinen et al., 2010; Kuwata et al., 2011). Furthermore, the evolution of OA's volatility distribution can provide an indirect way to gain insights about the very difficult-to-measure chemical composition and evolution of these compounds (Donahue et al., 2011).

Several studies have attempted to relate two of the three properties, but few have attempted to relate all three. Jimenez et al. (2009) proposed that the hygroscopicity of OA generally increases with the oxidation level expressed by the $\mathrm{O}: \mathrm{C}$ ratio and that there is also an inverse relationship between the O : C ratio and volatility. Tritscher et al. (2011) used a volatility and hygroscopicity tandem differential mobility analyzer (V/H-TDMA) and an Aerodyne High Resolution Time-ofFlight Aerosol Mass Spectrometer (HR-ToF-AMS, hereafter AMS) during the chemical aging of $\alpha$-pinene SOA and found that volatility decreased while hygroscopicity and the $\mathrm{O}: \mathrm{C}$ ratio remained fairly constant. Cerully et al. (2015) used a TD followed by a CCN counter, a scanning mobility particle sizer (SMPS), and an AMS in parallel and observed small changes in hygroscopicity for ambient OA components with dramatically different volatilities and concluded that the more volatile compounds were more hygroscopic than the remaining material. Several other studies (Poulain et al., 2010; Kuwata et al., 2011; Hong et al., 2014; Hildebrandt Ruiz et al., 2015) have investigated the effects of environmental parameters on one or all of these properties. However, these results are often inconclusive or even contradictory, and the links among these three properties are yet to be elucidated.

A theoretical framework (Nakao, 2017) has attempted to relate these three properties using the 2D-VBS framework (Donahue et al., 2011). The approach utilized correlations between the $\mathrm{O}: \mathrm{C}$ ratio, volatility, and hygroscopicity to predict lines of constant $\kappa$ in the 2D-VBS. The study concluded that relatively volatile $\mathrm{OA}$ components with a low $\mathrm{O}: \mathrm{C}$ ratio can have the same hygroscopicity as OA with lower volatility and a higher $\mathrm{O}: \mathrm{C}$ ratio.

One major obstacle pertaining to an experimentally determined relationship between these three properties for ambient aerosols is the often unknown or uncertain composition. The AMS can quantify the concentrations of the nonrefractory inorganic aerosol components as well as the total organic aerosol concentration, with further separation of the OA into components provided by techniques like positive matrix factorization (PMF). However, the analysis of the 
combined measurements of all three properties remains challenging.

The purpose of this work is the development of a method for the synchronous measurement of OA hygroscopicity, oxidation level, and volatility. In the next section, we describe the technique that utilizes a suite of aerosol instrumentation to measure these properties. Then, the method is tested with $\alpha$-pinene ozonolysis SOA. This SOA system has been studied extensively, so it can be a useful first test for the proposed experimental approach. Our objective is not to perform a comprehensive study of the properties of this SOA (which depend on SOA levels, relative humidity, etc.) but rather to use it as a pilot study. Finally, a data analysis technique is developed to interpret and synthesize the corresponding measurements.

\section{Methodology}

\subsection{Instrument setup}

A schematic of the experimental setup can be seen in Fig. 1. Particles are sampled through either a TD or a by-pass (BP) line via two three-way valves, and then the sample stream is split using a T union between an AMS and a differential mobility analyzer (DMA, TSI, model 3081). The stream from the DMA is split again with a T union between a condensation particle counter (CPC, TSI, model 3010/72) and a CCN counter (CCNC, Droplet Measurement Technologies). In this study, the AMS used a flow rate of $0.1 \mathrm{~L} \mathrm{~min}^{-1}$, while the CPC and the CCNC used 0.3 and $0.5 \mathrm{~L} \mathrm{~min}^{-1}$, respectively. The sheath flow in the DMA was set to $8 \mathrm{~L} \mathrm{~min}^{-1}$ to allow for a $10: 1$ sheath-to-aerosol flow ratio as the particles were classified. The upscan of the DMA was set to $120 \mathrm{~s}$, and the downscan was set to $15 \mathrm{~s}$.

In a typical experiment, once particles are ready for sampling, they pass through the TD at the first temperature set point for $15-25 \mathrm{~min}$. Then, the particles are sent through the BP as the temperature of the TD increases (another 15$25 \mathrm{~min}$ ). Once the TD reaches the next set point, the particles are directed through the TD for the same sampling period, and this process is repeated until measurements at all desired temperatures have been obtained. Total sampling time for 45 temperature set points is around $2.5-3.5 \mathrm{~h}$. Set points for the TD start at the lowest temperature and always increase.

\subsection{Hygroscopicity}

Hygroscopicity measurements were made with a CCNC, which generates supersaturations by exploiting water's higher mass diffusivity than heat's thermal diffusivity in air (Roberts and Nenes, 2005). The CCNC's fast response time allows it to be coupled to an SMPS, a technique called scanning mobility CCN analysis (SMCA; Moore et al., 2010). In our experiments, polydisperse aerosol was charged with a Po-210 neutralizer and then entered a DMA where the parti-

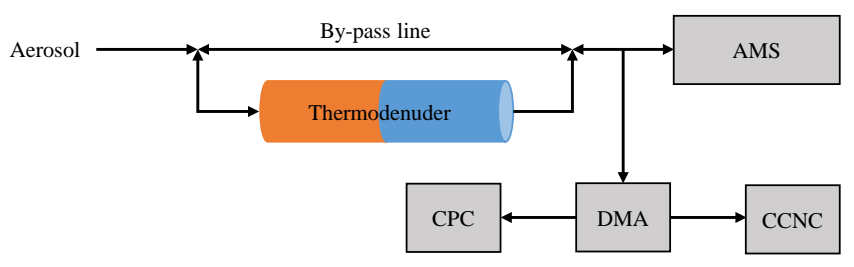

Figure 1. Schematic of the experimental setup for the hygroscopicity, oxidation level, and volatility measurements. The sampling technique employs a TD to measure volatility, an AMS to study the oxidation level, and a CCNC to determine hygroscopic activity.

cles were classified by their electrical mobility and counted by a CPC and the CCNC as the DMA voltage was scanned. Particle number concentrations (CNs) and size distributions were obtained from the SMPS using the AIM software. CCN concentrations and size distributions were obtained following the technique described in Moore et al. (2010). The SMPS and CCNC size distributions were aligned by matching the minimum in concentration that occurs during the transition between the DMA upscan and downscan. An activation curve was produced by dividing the $\mathrm{CCN}$ concentration by the $\mathrm{CN}$ concentration at each size. The activation diameter was calculated by fitting the activation curve to a sigmoidal function:

$$
\frac{\mathrm{CCN}}{\mathrm{CN}}=\frac{B}{\left(1+\frac{D_{\mathrm{d}}}{D_{\mathrm{p} 50}}\right)^{c}},
$$

where $\mathrm{CCN} / \mathrm{CN}$ is the fraction of activated particles; $B$ and $c$ describe the asymptote and slope of the sigmoid, respectively; $D_{\mathrm{d}}$ is the dry diameter; and $D_{\mathrm{p} 50}$ is the diameter at which $50 \%$ of the particles activate for a symmetric size distribution, which corresponds to the activation diameter.

The method to determine $\kappa$ follows the analysis done by Petters and Kreidenweis (2007) and will be explained briefly here. The defining equation is known as the $\kappa$-Köhler equation:

$$
S=\frac{D^{3}-D_{\mathrm{d}}^{3}}{D^{3}-D_{\mathrm{d}}^{3}(1-\kappa)} \exp \left(\frac{4 \sigma M_{\mathrm{w}}}{R T \rho_{\mathrm{w}} D}\right),
$$

where $S$ is the saturation ratio, $D$ is the wet particle diameter, $D_{\mathrm{d}}$ is the dry diameter, $\sigma$ is the surface tension of the solution-air interface, $M_{\mathrm{w}}$ is the molecular weight of water, $R$ is the universal gas constant, $T$ is the temperature, and $\rho_{\mathrm{W}}$ is the density of water. For a selected $D_{\mathrm{d}}$ and $\kappa$, the critical supersaturation, $S_{\mathrm{c}}$, can be computed from the maximum of Eq. (2). Then, lines of constant $\kappa$ can be obtained by plotting $\log \left(S_{\mathrm{c}}\right)$ as a function of $\log \left(D_{\mathrm{d}}\right)$. To estimate $\kappa$, experimentally determined activation diameters at different supersaturations were added to the $\log \left(S_{\mathrm{c}}\right)-\log \left(D_{\mathrm{d}}\right)$ plot, and the $\kappa$ was estimated by which isopleth fit the data. 


\subsection{Oxygen content}

An AMS was used to monitor the aerosol's composition. In our experiments, the AMS was operated in the V mode (DeCarlo et al., 2006) and used an averaging time of $1 \mathrm{~min}$. The data were analyzed in Igor Pro 6.22A (Wavemetrics) using "Squirrel" version 1.56D for unit mass resolution analysis and "Pika" version 1.15D for high-resolution analysis. The $\mathrm{O}: \mathrm{C}$ ratios reported here were calculated using the Canagaratna et al. (2015) method.

\subsection{Volatility}

Volatility measurements were made with the TD and the SMPS. These instruments were used to generate thermograms. To calculate the MFR, we divided the TD mass at each SMPS measurement by an interpolated BP mass using the BP measurements before and after the TD measurements. The MFR represents the fraction of particle mass that did not evaporate in the TD. The thermogram can be combined with a TD model (Riipinen et al., 2010), which describes the multicomponent OA evaporation to calculate the OA volatility distribution. The fitting algorithm has been described and evaluated by Karnezi et al. (2014). The 1D-VBS (Donahue et al., 2006) is used here, which discretizes the volatility distribution into logarithmically spaced bins based on an effective saturation concentration, $C^{*}$.

The TD used for this study consisted of two parts: a heating section and a cooling section. The heating section is $0.61 \mathrm{~m}$ long and is surrounded by heating tape to control the temperature. The cooling section is also $0.61 \mathrm{~m}$ long and contains activated carbon to avoid any recondensation while the aerosol returns to room temperature. Aerosol passes through the entire TD via $3.81 \mathrm{~cm}$ tubing. Therefore, after accounting for all of the flows, there will be laminar flow in the TD, resulting in a centerline residence time of $23 \mathrm{~s}$ at $298 \mathrm{~K}$ in the heating section, but the residence time will be shorter for the higher temperatures used in this study.

As particles pass through the TD, some of the mass will evaporate, but some particles will also be lost to the walls. To characterize these losses, $\mathrm{NaCl}$ particles were generated and passed through the BP and TD alternately for several temperatures. By comparing the size distributions through the $\mathrm{BP}$ and TD, the particle losses were quantified as a function of temperature and particle size for the flow rate used in our experiments (Fig. S1 in the Supplement). Particle losses increased with temperature in the TD but were fairly low $\left(<25 \%\right.$ at $\left.125^{\circ} \mathrm{C}\right)$ and roughly constant over the size range of interest in this study $(50-250 \mathrm{~nm})$.

\subsection{Smog chamber setup}

All experiments were conducted in the Carnegie Mellon University smog chamber, a $10 \mathrm{~m}^{3}$ Teflon (Welch Fluorocarbon) reactor suspended in a temperature-controlled room
(Pathak et al., 2007). Before each experiment, the chamber was flushed overnight with purified air under UV illumination (GE, model 10526 and 10244) to remove any potential contaminants. Purified air was generated by passing compressed air through a high-efficiency particulate air (HEPA) filter to remove any particles, an activated carbon filter to remove any vapors, and silica gel to maintain the relative humidity $(\mathrm{RH})$ at less than $5 \%$.

\section{System test with ammonium sulfate aerosol}

To determine whether the proposed and rather complex setup of several instruments operating together in series and in parallel was operating properly, a $1 \mathrm{gL}^{-1}$ solution of ammonium sulfate was pumped through an atomizer (TSI, model 3075) at a constant rate of $90 \mathrm{~mL} \mathrm{~h}^{-1}$ using a constantoutput syringe pump (Braintree Scientific, model BS-300). Before entering the chamber, the resulting droplets passed through a silica gel dryer to produce dry particles. Ammonium sulfate particles have traditionally been used in TD and $\mathrm{CCN}$ tests because they are easy to produce and are relatively non-volatile at temperatures below approximately $100^{\circ} \mathrm{C}$ (Clarke, 1991; An et al., 2007). Furthermore, they are very hygroscopic with well-known properties. Their CCN activity has been shown to be consistent with Köhler theory (Cruz and Pandis, 1997). At different TD temperatures below $100^{\circ} \mathrm{C}$, ammonium sulfate particles should behave the same hygroscopically as the particles passing through the BP.

The thermogram for the ammonium sulfate particles is shown in Fig. 2a. No aerosol mass evaporated at 50 and $100^{\circ} \mathrm{C}$, but nearly all of the mass evaporated at $150^{\circ} \mathrm{C}$. The remaining material at $150^{\circ} \mathrm{C}$ also included impurities in the ammonium sulfate solution that do not evaporate at that temperature. The measured activation diameter for the BP, two TD temperatures $\left(50\right.$ and $\left.100^{\circ} \mathrm{C}\right)$, and Köhler theory from this experiment are shown in Fig. 2b. The activation diameters at all supersaturations through the BP and the TD agreed with Köhler theory, confirming that our system operates properly for at least this simple model system.

\section{Application to $\alpha$-pinene ozonolysis SOA}

The experimental approach was then applied to SOA. For these experiments, $\alpha$-pinene (Sigma-Aldrich, $\geq 99 \%$ ) was injected into the chamber using a heated septum injector with purified air as carrier flow. Ozone was generated by an ozone generator (AZCO, model HTU-500ACPS) and injected into the chamber after the $\alpha$-pinene injection. Table 1 displays the different experimental conditions examined in this pilot study. The initial ozone concentration and RH remained almost the same in all experiments, but the initial $\alpha$-pinene concentration and water supersaturation in the $\mathrm{CCNC}$ were varied. 

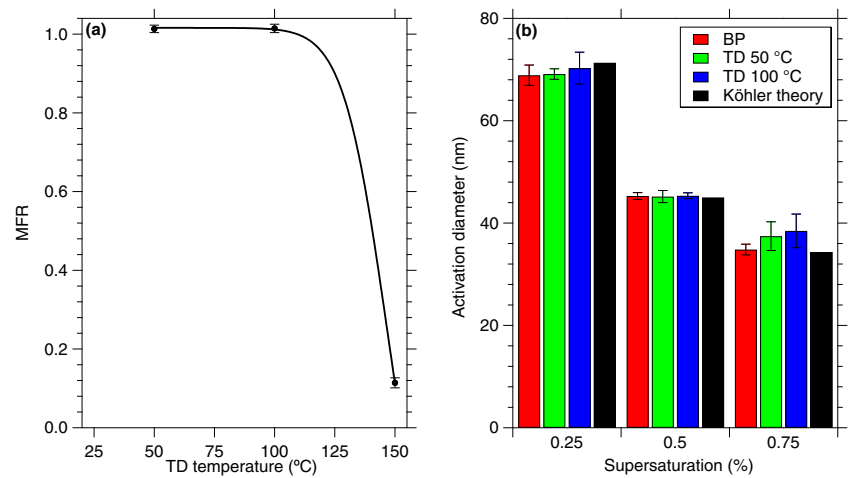

Figure 2. (a) The thermogram for ammonium sulfate aerosol. (b) The calculated activation diameter at three CCNC supersaturations for the $\mathrm{BP}$ (red), two TD temperatures (green and blue), and Köhler theory (black) for ammonium sulfate aerosol. The error bars represent 1 standard deviation of the mean.

Table 1. Description of experimental conditions used in this study.

\begin{tabular}{lrrrrr}
\hline Exp. & $\begin{array}{r}\alpha \text {-Pinene } \\
(\mathrm{ppb})\end{array}$ & $\begin{array}{r}\text { Ozone } \\
(\mathrm{ppb})\end{array}$ & $\begin{array}{r}\text { RH } \\
(\%)\end{array}$ & $\begin{array}{r}\text { Supersaturation } \\
(\%)^{*}\end{array}$ & $\begin{array}{r}\text { Max OA } \\
\left(\mu \mathrm{g} \mathrm{m}^{-3}\right)\end{array}$ \\
\hline 1 & 100 & $\sim 500$ & $<15$ & 0.20 & 108 \\
2 & 50 & $\sim 500$ & $<15$ & 0.30 & 35 \\
3 & 50 & $\sim 500$ & $<15$ & 0.25 & 39 \\
4 & 50 & $\sim 500$ & $<15$ & 0.27 & 46 \\
\hline
\end{tabular}

* CCNC supersaturation was held constant during experiments in order to allow sufficient time for an average activation diameter to be measured at each TD temperature.

For Experiment 1, $100 \mathrm{ppb}$ of $\alpha$-pinene was injected into the chamber, immediately followed by around $500 \mathrm{ppb}$ of ozone. After $1 \mathrm{~h}$ of reaction time, the ozonolysis was practically complete, and particles were sampled through the TD and BP alternatively for five temperatures $(25,50,75,100$, and $125^{\circ} \mathrm{C}$ ). The SOA mass concentration, measured with the SMPS assuming a density of $1.4 \mathrm{~g} \mathrm{~cm}^{-3}$ (Kostenidou et al., 2007), increased immediately following the ozone injection and reached a maximum of around $108 \mu \mathrm{g} \mathrm{m}^{-3}$. The SOA then began decreasing due to particles being lost to the chamber walls.

To check that the SOA sampled at the beginning of the experiment was similar to the SOA sampled at the end of the experiment, we compared the corresponding AMS mass spectra using the theta angle $(\theta)$ proposed by Kostenidou et al. (2009). The $\theta$ angle between the mass spectra of the BP at the beginning of the experiment and the $\mathrm{BP}$ before passing through the $\mathrm{TD}$ at $125^{\circ} \mathrm{C}$ was $2.4^{\circ}$, indicating that the change of the SOA's spectra during the experiment was minimal. The same behavior was observed in all other experiments in this study.

The thermogram, TD model prediction, and corresponding estimated volatility distribution, using the Karnezi et al. (2014) algorithm, for Experiment 1 are shown in Fig. 3. The TD model reproduced the MFR measurements well. For
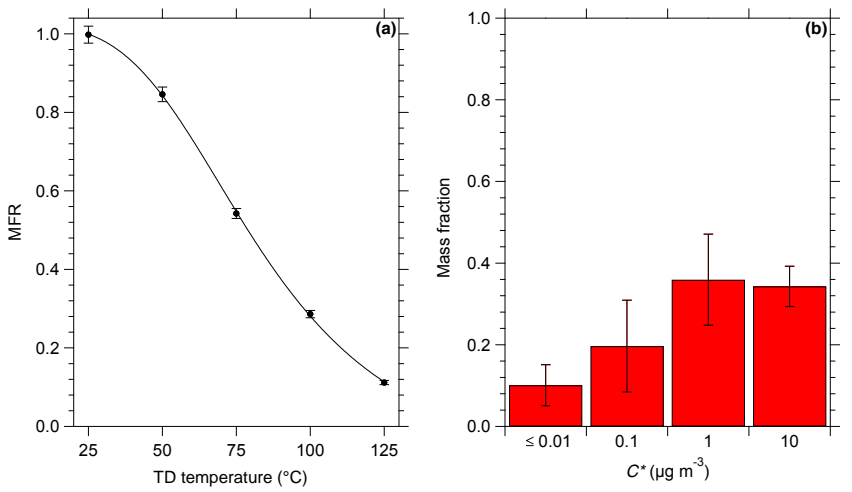

Figure 3. (a) Thermogram, corrected for losses in the TD, for Experiment 1 with the fit from the TD model (Riipinen et al., 2010; Karnezi et al., 2014). The error bars represent 1 standard deviation of the mean. (b) SOA volatility distribution for Experiment 1 using the 1D-VBS framework (Donahue et al., 2006). The error bars correspond to 1 standard deviation of the solution calculated by the model.

this experiment with $\mathrm{OA}$ around $100 \mu \mathrm{g} \mathrm{m}^{-3}$, over two-thirds of the SOA had an effective saturation concentration $\left(C^{*}\right)$ of 1 or $10 \mu \mathrm{g} \mathrm{m}^{-3}, 20 \%$ had a $C^{*}=0.1 \mu \mathrm{g} \mathrm{m}^{-3}$, and $10 \%$ had a $C^{*}=0.01 \mu \mathrm{g} \mathrm{m}^{-3}$. The $C^{*}=0.01 \mu \mathrm{g} \mathrm{m}^{-3}$ bin also includes compounds with even lower volatilities. An effective enthalpy of vaporization, $\Delta H_{\text {vap }}$, equal to $65 \mathrm{~kJ} \mathrm{~mol}^{-1}$ was estimated assuming an accommodation coefficient equal to unity.

Our TD results are comparable to those in the literature for $\alpha$-pinene ozonolysis SOA. At $100^{\circ} \mathrm{C}$, the MFR for the SOA in Experiment 1 was $0.29 \pm 0.01$. Huffman et al. (2009) and Poulain et al. (2010) reported a MFR of around 0.35 at $100^{\circ} \mathrm{C}$, but their SOA levels were several times larger (46 ), and their residence times were about half of the one used in this study. Kuwata et al. (2011) observed a MFR of 0.50 at a TD temperature of $100^{\circ} \mathrm{C}$ for lower SOA levels (25$\left.37 \mu \mathrm{g} \mathrm{m}^{-3}\right)$ and a significantly shorter residence time $(0.4 \mathrm{~s})$. This further reiterates the difficulty in comparing volatility studies using different experimental methods, which is why our study uses the 1D-VBS, allowing for comparisons between studies, regardless of TD operating conditions.

In addition to volatility, the SOA's oxygen content was also measured. Figure 4 shows the average $\mathrm{O}: \mathrm{C}$ ratio through the BP and TD at different temperatures for Experiment 1. The O : C ratio started around 0.49 and decreased at higher temperatures, ending at 0.39 while passing through the TD at $125^{\circ} \mathrm{C}$. All of the $\mathrm{O}: \mathrm{C}$ ratios at a TD temperature of $50^{\circ} \mathrm{C}$ and above were statistically lower than the $\mathrm{O}: \mathrm{C}$ ratios through the $\mathrm{BP}$ and $\mathrm{TD}$ at $25^{\circ} \mathrm{C}$ (one-tailed $t$ test, $p<0.0001$ ). The final O : C ratio of 0.39 corresponds to $11 \%$ of the least volatile SOA (Fig. 3a). When compared to an $\mathrm{O}: \mathrm{C}$ ratio of 0.49 through the $\mathrm{BP}$, an $\mathrm{O}: \mathrm{C}$ ratio of 0.39 through the $\mathrm{TD}$ at $125^{\circ} \mathrm{C}$ indicates that the least volatile ma- 


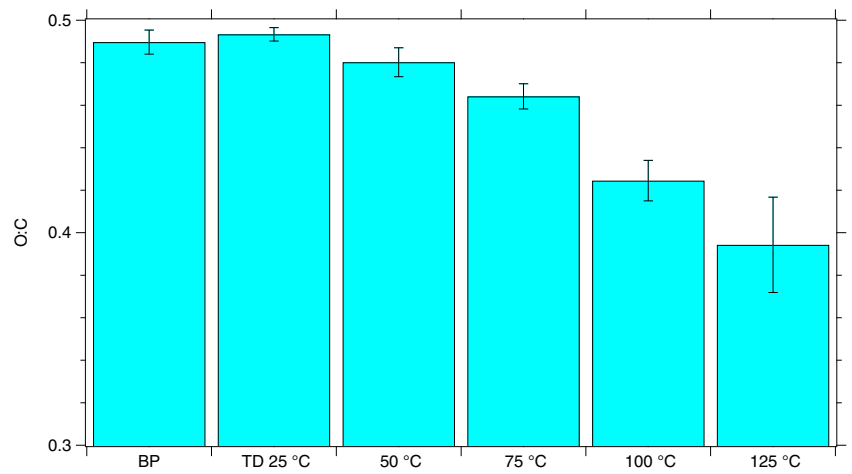

Figure 4. The average $\mathrm{O}: \mathrm{C}$ ratio observed through the $\mathrm{BP}$ and several TD temperatures for Experiment 1 . The error bars represent 1 standard deviation of the mean. The $\mathrm{O}: \mathrm{C}$ ratios at a TD temperature of $50^{\circ} \mathrm{C}$ and greater were statistically smaller than the values at the $\mathrm{BP}$ and the $\mathrm{TD}$ at $25^{\circ} \mathrm{C}$.

terial in these experiments contained components that were not very oxidized at least on average.

Our $\mathrm{O}: \mathrm{C}$ ratios fall into the reported range of $\mathrm{O}: \mathrm{C}$ ratios in the literature for $\alpha$-pinene ozonolysis SOA (Huffman et al., 2009; Massoli et al., 2010; Kuwata et al., 2011; Tritscher et al., 2011). Kuwata et al. (2011) observed that the $\mathrm{O}: \mathrm{C}$ ratio dropped sometimes due to high TD temperatures but argued that increases in the mass concentration were the main cause of the $\mathrm{O}: \mathrm{C}$ ratio decreasing. Poulain et al. (2010) reported that the more oxygenated compounds were less volatile than the less oxygenated ones, which contradicts our results, but their conclusions were based on changing the $\mathrm{RH}$ at which the SOA was formed, which could impact the SOA's response to heat treatment.

The SOA's hygroscopic activity was also measured at the same time. The measured activation diameter as a function of temperature for Experiment 1 is shown in Fig. 5a. The activation diameter of all the SOA remained fairly constant around $140 \mathrm{~nm}(0.2 \%$ supersaturation $)$ during the experiment and as the temperature in the TD increased to $50^{\circ} \mathrm{C}$. However, for even higher TD temperatures, the activation diameter increased, ending at $155 \mathrm{~nm}(0.2 \%$ supersaturation) for the least volatile $11 \%$ of the SOA. The activation diameters through the TD at temperatures of $75^{\circ} \mathrm{C}$ and greater were statistically larger than the activation diameter through either the BP or TD at $25^{\circ} \mathrm{C}$ (one-tailed $t$ test, $p<0.0001$ ). This indicates that the least volatile components of the $\alpha$ pinene ozonolysis SOA also contained components that were not very hygroscopic. This is contradictory to the hypothesis of Jimenez et al. (2009), who proposed that the least volatile material is usually the most processed and therefore the most hygroscopic. However, the least volatile material in all our experiments had consistently the lowest $\mathrm{O}: \mathrm{C}$ ratio and highest activation diameter, indicating a more complex relationship between hygroscopicity, oxidation level, and volatility in this system. There is, however, the possibility that chemi-
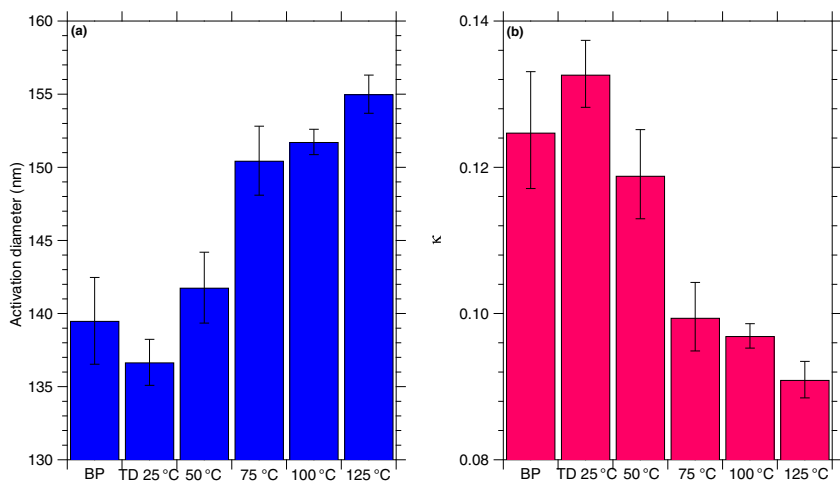

Figure 5. (a) The average activation diameter observed at $0.2 \%$ supersaturation in the CCNC for Experiment 1. The error bars represent 1 standard deviation of the mean. (b) The estimated $\kappa$ values for Experiment 1. The error bars were obtained by estimating the $\kappa$ at \pm 1 standard deviation of the average activation diameter measured. The values at TD temperatures of $75^{\circ} \mathrm{C}$ and greater were statistically different from the values at the $\mathrm{BP}$ and the $\mathrm{TD}$ at $25^{\circ} \mathrm{C}$.

cal changes that occurred to the particles within the TD rendered them less $\mathrm{CCN}$ active.

The estimated $\kappa$ parameters as a function of TD temperature in Experiment 1 can be seen in Fig. 5b. Similar to the pattern observed with the activation diameters, the $\kappa$ through the TD at temperatures greater than or equal to $75^{\circ} \mathrm{C}$ were statistically lower than the $\kappa$ through either the BP or TD at $25{ }^{\circ} \mathrm{C}$ (one-tailed $t$ test, $p<0.0001$ ), reiterating the notion that the least volatile SOA contained components that were less hygroscopic than the rest of the SOA. The $\kappa$ 's obtained in all experiments were similar to observed values for $\alpha$-pinene ozonolysis SOA in other CCNC studies (Engelhart et al., 2008; Massoli et al., 2010; Frosch et al., 2011), and the decrease in hygroscopicity after heat treatment has also been reported by Kuwata et al. (2011).

Detailed results for Experiments 2, 3, and 4 can be found in the supplement to this paper. They were all conducted with $50 \mathrm{ppb}$ of $\alpha$-pinene and around $500 \mathrm{ppb}$ of ozone, generating around $40 \mu \mathrm{g} \mathrm{m}^{-3}$ of SOA. In general, the $\mathrm{O}: \mathrm{C}$ ratios and $\kappa$ 's were slightly higher than those in Experiment 1. However, as with Experiment 1, these experiments also resulted in statistically lower $\mathrm{O}: \mathrm{C}$ ratios and $\kappa$ 's through the TD at higher temperatures. The following section proposes and discusses a novel analysis method to further investigate this behavior.

\section{Relating hygroscopicity and $\mathrm{O}: \mathrm{C}$ to volatility}

The above data can be used to estimate the SOA's hygroscopicity and oxidation level as a function of volatility. The compounds in a volatility bin, $i$, have an average $\mathrm{O}: \mathrm{C}$ ratio, $[\mathrm{O}: \mathrm{C}]_{i}$, and hygroscopicity parameter, $\kappa_{i}$. The $\mathrm{O}: \mathrm{C}$ ratio and $\kappa$ distributions as a function of volatility can be determined utilizing the data obtained at each TD temperature by 


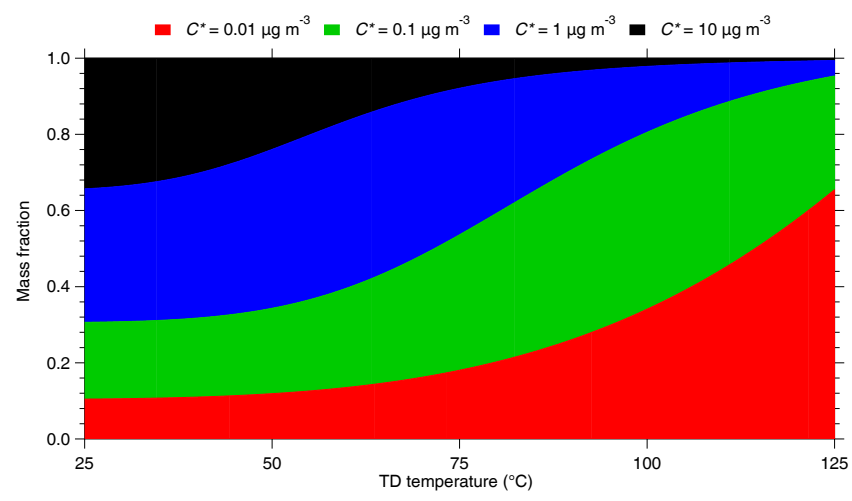

Figure 6. The estimated mass fractions for each volatility bin as a function of TD temperature for Experiment 1. Red represents the $C^{*}=0.01 \mu \mathrm{g} \mathrm{m}^{-3}$ bin, green the $C^{*}=0.1 \mu \mathrm{g} \mathrm{m}^{-3}$ bin, blue the $C^{*}=1 \mu \mathrm{g} \mathrm{m}^{-3}$ bin, and black the $C^{*}=10 \mu \mathrm{g} \mathrm{m}^{-3}$ bin.

using the following equations:

$$
\begin{aligned}
{[\mathrm{O}: \mathrm{C}]_{\mathrm{TD}} } & =\sum_{i=1}^{n} x_{i, \mathrm{TD}}[\mathrm{O}: \mathrm{C}]_{i} \\
\kappa_{\mathrm{TD}} & =\sum_{i=1}^{n} x_{i, \mathrm{TD}} \kappa_{i},
\end{aligned}
$$

where $[\mathrm{O}: \mathrm{C}]_{\mathrm{TD}}$ and $\kappa_{\mathrm{TD}}$ are the measured $\mathrm{O}: \mathrm{C}$ ratio and $\kappa$ at a TD temperature, $x_{i, \mathrm{TD}}$ is the SOA mass fraction in the $i$ th bin at the same temperature, and $[\mathrm{O}: \mathrm{C}]_{i}$ and $\kappa_{i}$ are the unknown $\mathrm{O}: \mathrm{C}$ ratio and $\kappa$ for the $i$ th bin. The mass fraction for each bin as a function of TD temperature is estimated by the TD model. An example for Experiment 1 is shown in Fig. 6. As expected, as the temperature in the TD increases, the more volatile components evaporate, and the SOA is comprised of mostly low-volatility compounds.

For a future extension of the approach to ambient aerosols, the equations remain the same. The OA components could be separated into different groups using PMF with corresponding $\kappa$ 's, $\mathrm{O}: \mathrm{C}$ ratios, and volatility distributions. This is similar to how Paciga et al. (2016) used PMF on ambient OA in Paris and generated volatility distributions for each factor.

Equation (3) assumes implicitly that the SOA in the various volatility bins has a similar average number of carbon atoms per molecule and also similar average molecular weights. These are clearly zeroth-order approximations and introduce corresponding uncertainties in the estimated $\mathrm{O}: \mathrm{C}$ ratio for each bin. Equation (4) is based on the work of Petters and Kreidenweis (2007) and assumes that the average density of the material in the various volatility bins is similar. These equations can be used to generate a system of equations for both the $\mathrm{O}: \mathrm{C}$ ratios and $\kappa$ 's that can be solved separately.

First we focus on how to determine the $\mathrm{O}: \mathrm{C}$ ratio distribution as a function of volatility, but the process to determine the $\kappa$ distribution is exactly the same. Each measurement at a specific TD temperature results in one equation of the form of Eq. (3) with unknown $\mathrm{O}: \mathrm{C}$ ratios for the various volatility bins. For example, for Experiment 1, we used
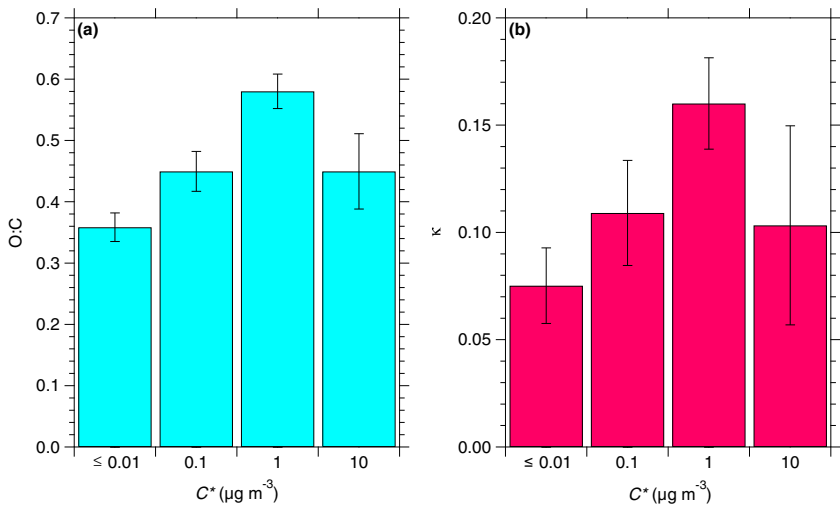

Figure 7. The (a) $\mathrm{O}: \mathrm{C}$ ratio and (b) $\kappa$ distributions for the volatility bins characterized in this study for $\alpha$-pinene ozonolysis SOA. The error bars represent 1 standard deviation of the mean obtained from the least squares solver.

the average $\mathrm{O}: \mathrm{C}$ ratios from Fig. 4 and the mass fractions from Fig. 6 at each TD temperature to generate five equations with four unknowns. The combination of the results of all experiments led to 18 equations (five from Experiment 1, four from Experiment 2, etc.) with four unknown $\mathrm{O}: \mathrm{C}$ ratios $\left([\mathrm{O}: \mathrm{C}]_{0.01},[\mathrm{O}: \mathrm{C}]_{0.1}\right.$, etc. $)$. The optimum values of the $\mathrm{O}: \mathrm{C}$ ratios were determined by minimizing the squared residual between the measured $\left([\mathrm{O}: \mathrm{C}]_{\mathrm{TD}}\right)$ and predicted $\left(\sum_{i=1}^{n} x_{i, \mathrm{TD}}[\mathrm{O}: \mathrm{C}]_{i}\right) \mathrm{O}: \mathrm{C}$ ratios. Matlab's linear least squares solver, lscov, was used for this task.

The results for the $\mathrm{O}: \mathrm{C}$ ratio distribution can be seen in Fig. 7a. The $C^{*}=0.01 \mu \mathrm{g} \mathrm{m}^{-3}$ bin had the lowest $\mathrm{O}: \mathrm{C}$ ratio, while the $C^{*}=1 \mu \mathrm{g} \mathrm{m}^{-3}$ bin had the highest values. The $C^{*}=0.1$ and $10 \mu \mathrm{g} \mathrm{m}^{-3}$ bins had nearly identical $\mathrm{O}: \mathrm{C}$ ratios. These results suggest that, for this system and the conditions examined, the relationship between the $\mathrm{O}: \mathrm{C}$ ratio and effective volatility was not monotonic.

The hygroscopicity parameter, $\kappa$, distribution was determined in exactly the same way, and the results are depicted in Fig. 7b. The O:C ratios and corresponding $\kappa$ 's for each volatility bin were correlated extremely well $\left(r^{2}>0.99\right.$, Fig. S14), which has been reported in numerous studies (Rickards et al., 2013). The SOA in the $C^{*}=1 \mu \mathrm{g} \mathrm{m}^{-3}$ bin had the highest hygroscopicity, while the most and least volatile components had lower $\kappa$ values.

In order to determine the robustness of our solution, we compared the predicted $\mathrm{O}: \mathrm{C}$ ratios and $\kappa$ 's at each TD temperature to the measured values for every experiment. For the predicted values, we used the distributions in Fig. 7, multiplied them by their corresponding mass fractions, and summed the products up at each TD temperature. The predicted versus measured $\mathrm{O}: \mathrm{C}$ ratios and $\kappa$ 's can be seen in Figs. 8 and 9, respectively. The $\mathrm{O}: \mathrm{C}$ ratio distribution appears to be a better predictor than the $\kappa$ distribution because most of the predicted $\mathrm{O}: \mathrm{C}$ ratios lie on the $1: 1$ line or very 


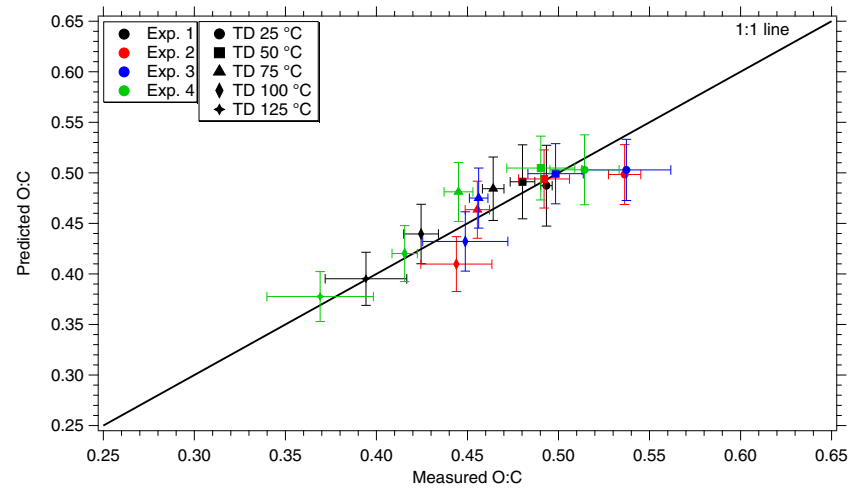

Figure 8. The predicted versus measured $\mathrm{O}: \mathrm{C}$ ratios for all TD temperatures in all of the experiments. The color indicates the experiment number, and the symbol indicates the TD temperature. The error bars for the predicted $\mathrm{O}: \mathrm{C}$ ratios were obtained by predicting the $\mathrm{O}: \mathrm{C}$ ratios using the $\mathrm{O}: \mathrm{C}$ ratio distribution at \pm 1 standard deviation in Fig. 7a.

close to it, while the predicted $\kappa$ 's were more scattered. However, essentially all of the predicted values were very close to the measured ones, and the remaining values were within 1 standard deviation of the measured values.

Figure 7 presents results that could, at least in principle, connect different, or even contradicting, results from previous studies. For example, Jimenez et al. (2009) proposed that hygroscopicity and the $\mathrm{O}: \mathrm{C}$ ratio increase as volatility decreases. However, Cerully et al. (2015) reported contradicting results: that the more volatile components of ambient $\mathrm{OA}$ were more hygroscopic than the remaining material. The results presented here, albeit over a small range and only for $\alpha$-pinene ozonolysis SOA, provide a context in which both conclusions can be true. As the volatility decreased from a $C^{*}=10$ to $1 \mu \mathrm{g} \mathrm{m}^{-3}$, the $\mathrm{O}: \mathrm{C}$ ratio and $\kappa$ increased (i.e., supporting the results of Jimenez et al., 2009), but the O:C ratio and $\kappa$ of the more volatile $C^{*}=1 \mu \mathrm{g} \mathrm{m}^{-3}$ bin were higher than those of the $C^{*}=0.01$ and $0.1 \mu \mathrm{g} \mathrm{m}^{-3}$ bins (i.e., supporting the results of Cerully et al., 2015). Therefore, the approach described in this study can provide a more comprehensive method to determine the relationship between OA hygroscopicity, oxidation level, and volatility.

\subsection{Sensitivity analysis}

As a test, we optimized the system of equations again, but this time we systematically eliminated one equation so that, when we optimized the solution, we were only using 17 equations. After optimizing the system, we replaced the missing equation and removed another one. This test allowed us to determine if there was one measurement that significantly affected the results in Fig. 7. In all cases but one, the average values were nearly identical to the distributions from Fig. 7, demonstrating that one equation was not overly influencing the results. The only substantial deviation from Fig. 7

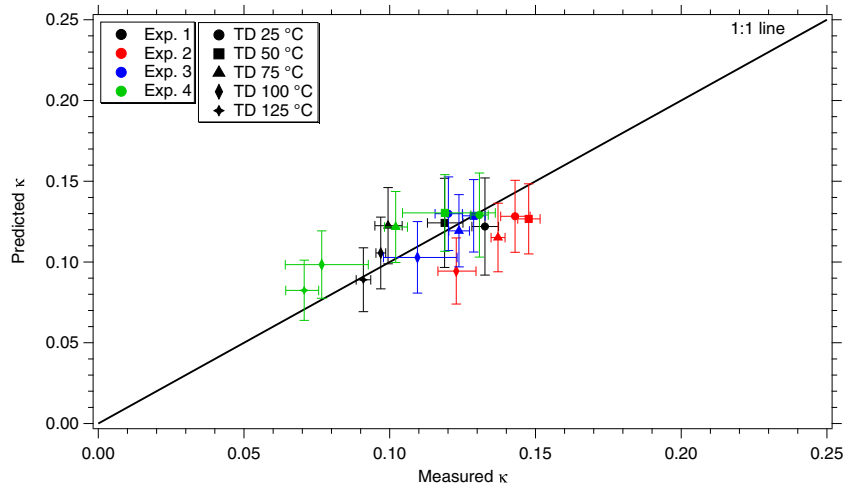

Figure 9. The predicted versus measured $\kappa$ 's for all TD temperatures in all of the experiments. The color indicates the experiment number, and the symbol indicates the TD temperature. The error bars for the predicted $\kappa$ 's were obtained by predicting the $\kappa$ 's using the $\kappa$ distribution at \pm 1 standard deviation in Fig. $7 \mathrm{~b}$.

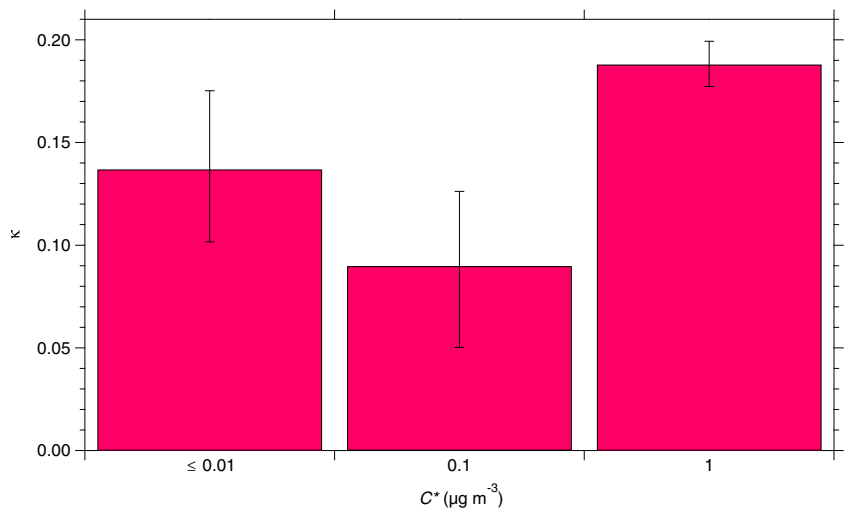

Figure 10. The $\kappa$ distribution that resulted from solving Eq. (4) for TD temperatures greater than $50^{\circ} \mathrm{C}$ and the three lowest bins for Experiment 2. The error bars represent 1 standard deviation obtained by solving the equations at \pm 1 standard deviation of the measured $\kappa$.

was observed for the $C^{*}=10 \mu \mathrm{g} \mathrm{m}^{-3}$ bin when the $\kappa$ equation through the TD at $25^{\circ} \mathrm{C}$ for Experiment 1 was omitted. When the system was optimized without this equation, the $\kappa$ for this bin decreased from 0.10 to 0.05 . Since the mass fraction of the $C^{*}=10 \mu \mathrm{g} \mathrm{m}^{-3}$ bin for Experiment 1 was almost double the next-highest mass fraction in any measurement, it holds significantly more information, and therefore, weight, in the optimization process and impacts the solution for this bin. However, even if the $\kappa$ for this bin changed when the corresponding measurement was omitted, the change is consistent with the large uncertainty bars for the $\kappa$ of the $C^{*}=10 \mu \mathrm{g} \mathrm{m}^{-3}$ bin in Fig. 7. This exercise suggests that our results appear to be relatively robust.

As seen in Fig. 9, the $\kappa$ distribution in Fig. 7 underpredicts all of the measured $\kappa$ 's from Experiment 2. In order to investigate the cause of this discrepancy, we used Eq. (4) to determine the $\kappa$ distribution just for Experiment 2. Since 
this experiment only had four TD temperatures (Fig. S2), four equations could be written with four unknowns. However, when the system of equations was solved, the solution provided reasonable $\kappa$ 's for the three lowest bins, but it produced a $\kappa=-0.15$ for the $C^{*}=10 \mu \mathrm{g} \mathrm{m}^{-3}$ bin. We hypothesized that the unreasonable value for the highest bin was due to the small mass fraction of the SOA in this bin at all temperatures (Fig. S5). At $25^{\circ} \mathrm{C}$, only $4 \%$ of the SOA had a $C^{*}=10 \mu \mathrm{g} \mathrm{m}^{-3}$, and those compounds completely evaporated as the temperature in the TD increased. Therefore, there was insufficient information to accurately estimate the properties of this bin for this experiment. To determine if this was true, we used Eq. (3) to solve for the $\mathrm{O}: \mathrm{C}$ ratio distribution for Experiment 2. When we solved the system of equations, the solution again provided reasonable $\mathrm{O}: \mathrm{C}$ ratios for the three lowest bins but produced an $\mathrm{O}: \mathrm{C}=2.16$ for the $C^{*}=10 \mu \mathrm{g} \mathrm{m}^{-3}$ bin. Since both solutions provided unreasonable values for the highest bin, we concluded that the method is unable to accurately estimate the properties of bins with very low concentrations (i.e., $x_{i}<0.1$ ). However, when experiments with different concentrations are combined, as we did with Experiments 1-4 above, the method is able to determine reasonable estimates for the bins' properties.

To address the uncertainty introduced by the low concentration of material in the $C^{*}=10 \mu \mathrm{g} \mathrm{m}^{-3}$ bin for Experiment 2, we ignored the $C^{*}=10 \mu \mathrm{g} \mathrm{m}^{-3}$ bin and removed the $\kappa$ equation at $25^{\circ} \mathrm{C}$. This approach implicitly assumes that the material in the $C^{*}=10 \mu \mathrm{g} \mathrm{m}^{-3}$ bin has evaporated at $50^{\circ} \mathrm{C}$, which is reasonable because the mass fraction for the bin is less than $2 \%$ at $50{ }^{\circ} \mathrm{C}$ (Fig. S5). This resulted in three equations with three unknown $\kappa$ 's. We solved the system of equations algebraically, and the results for the $\kappa$ distribution can be seen in Fig. 10. When compared to the $\kappa$ distribution in Fig. 7b, the $\kappa$ 's for the $C^{*}=0.1$ and $1 \mu \mathrm{g} \mathrm{m}^{-3}$ bins are the same within uncertainty $(0.09$ to 0.11 and 0.19 to 0.16 , respectively), but the $\kappa$ for the $C^{*}=0.01 \mu \mathrm{g} \mathrm{m}^{-3}$ bin is nearly twice that of the one in Fig. $7 b$ (0.14 to 0.08). This indicates that the SOA that had a $C^{*}=0.01 \mu \mathrm{g} \mathrm{m}^{-3}$ in Experiment 2 was more hygroscopic than indicated in Fig. 7b. To demonstrate this, we predicted the $\kappa$ 's for Experiment 2 again. In order to do this, we used the $\kappa$ 's for the three highest bins from Fig. 7b, but we used the $\kappa$ for the $C^{*}=0.01 \mu \mathrm{g} \mathrm{m}^{-3}$ bin estimated in Fig. 10. The results can be seen in Fig. S15. With the larger $\kappa$ for the $C^{*}=0.01 \mu \mathrm{g} \mathrm{m}^{-3}$ bin, the predicted $\kappa$ 's were nearly identical to the measured ones. This demonstrates the variability that can occur from experiment to experiment, but the analysis method developed here can examine experiments separately to determine the cause of the variability.

\section{Conclusions}

This study evaluates the feasibility of a novel measurement and analysis technique to quantify OA's hygroscopicity, O :C ratio, and volatility distribution. The experimental approach used a CCNC to study hygroscopicity, an AMS to determine the $\mathrm{O}: \mathrm{C}$ ratio, and a TD to evaluate volatility. The experimental setup was tested with SOA generated from the ozonolysis of $\alpha$-pinene. The results of these experiments revealed that the $\mathrm{O}: \mathrm{C}$ ratio and $\kappa$ decreased as the SOA passed through the TD at higher temperatures. This indicates that the lowest-volatility material in this system contained components that had lower $\mathrm{O}: \mathrm{C}$ ratios and $\kappa_{\mathrm{CCN}}$ 's. However, detailed characterization of the composition of the remaining compounds after the TD is required to quantify the contribution of chemical reactions to these observed changes.

An analysis technique to synthesize the data from this experimental setup was also developed. The results from this analysis confirmed that the SOA for this system had some low-volatility material with a low $\mathrm{O}: \mathrm{C}$ ratio and $\kappa$. It also showed that both low- and high-volatility compounds can have comparable oxidation levels and hygroscopicities.

This approach can be used to connect studies that were once thought to have contradicting results regarding the relationship between these three properties. Further chamber studies and ambient sampling are necessary in order to describe the relationship between OA hygroscopicity, oxidation level, and volatility not only for multiple SOA systems but also for ambient OA. This study was able to analyze a small portion of the 2D-VBS framework space, but this method can be utilized to help identify the relationship across the entire OA volatility axis. This approach also serves as an experimental branch to the theoretical framework proposed by Nakao (2017).

Data availability. Data are available upon request from Spyros Pandis (spyros@andrew.cmu.edu).

\section{The Supplement related to this article is available online at https://doi.org/10.5194/amt-10-4865-2017-supplement.}

Competing interests. The authors declare that they have no conflict of interest.

Acknowledgements. This work was supported by the National Science Foundation grant 1455244.

Edited by: Pierre Herckes

Reviewed by: Fred Brechtel and two anonymous referees

\section{References}

Alfarra, M. R., Paulsen, D., Gysel, M., Garforth, A. A., Dommen, J., Prêvôt, A. S. H., Worsnop, D. R., Baltensperger, U., and Coe, 
H.: A mass spectrometric study of secondary organic aerosols formed from the photooxidation of anthropogenic and biogenic precursors in a reaction chamber, Atmos. Chem. Phys., 6, 52795293, https://doi.org/10.5194/acp-6-5279-2006, 2006.

An, W. J., Pathak, R. K., Lee, B. H., and Pandis, S. N.: Aerosol volatility measurement using an improved thermodenuder: Application to secondary organic aerosol, J. Aerosol Sci., 38, 305314, https://doi.org/10.1016/j.jaerosci.2006.12.002, 2007.

Bahreini, R., Keywood, M. D., Ng, N. L., Varutbangkul, V., Gao, S., Flagan, R. C., Seinfeld, J. H., Worsnop, D. R., and Jimenez, J. L.: Measurements of secondary organic aerosol from oxidation of cycloalkenes, terpenes, and m-xylene using an aerodyne aerosol mass spectrometer, Environ. Sci. Technol., 39, 56745688, https://doi.org/10.1021/es048061a, 2005.

Brook, R. D., Rajagopalan, S., Pope, C. A., Brook, J. R., Bhatnagar, A., Diez-Roux, A. V., Holguin, F., Hong, Y., Luepker, R. V., Mittleman, M. A., Peters, A., Siscovick, D., Smith, S. C., Whitsel, L., and Kaufman, J. D.: Particulate matter air pollution and cardiovascular disease: An update to the scientific statement from the American Heart Association, Circulation, 121, 2331-2378, https://doi.org/10.1161/CIR.0b013e3181dbece1, 2010.

Canagaratna, M. R., Jimenez, J. L., Kroll, J. H., Chen, Q., Kessler, S. H., Massoli, P., Hildebrandt Ruiz, L., Forner, E., Williams, L. R., Wilson, K. R., Surratt, J. D., Donahue, N. M., Jayne, J. T., and Worsnop, D. R.: Elemental ratio measurements of organic compounds using aerosol mass spectrometry: Characterization, improved calibration, and implications, Atmos. Chem. Phys., 15, 253-272, https://doi.org/10.5194/acp-15-253-2015, 2015.

Cappa, C. D.: A model of aerosol evaporation kinetics in a thermodenuder, Atmos. Meas. Tech., 3, 579-592, https://doi.org/10.5194/amt-3-579-2010, 2010.

Cappa, C. D. and Wilson, K. R.: Evolution of organic aerosol mass spectra upon heating: Implications for OA phase and partitioning behavior, Atmos. Chem. Phys., 11, 1895-1911, https://doi.org/10.5194/acp-11-1895-2011, 2011.

Cerully, K. M., Bougiatioti, A., Hite Jr., J. R., Guo, H., Xu, L., $\mathrm{Ng}$, N. L., Weber, R., and Nenes, A.: On the link between hygroscopicity, volatility, and oxidation state of ambient and water-soluble aerosols in the southeastern United States, Atmos. Chem. Phys., 15, 8679-8694, https://doi.org/10.5194/acp15-8679-2015, 2015.

Clarke, A. D.: A thermo-optic technique for in situ analysis of sizeresolved aerosol physicochemistry, Atmos. Environ., 25, 635644, https://doi.org/10.1016/0960-1686(91)90061-B, 1991.

Cruz, C. N. and Pandis, S. N.: A study of the ability of pure secondary organic aerosol to act as cloud condensation nuclei, Atmos. Environ., 31, 2205-2214, https://doi.org/10.1016/S13522310(97)00054-X, 1997.

DeCarlo, P. F., Kimmel, J. R., Trimborn, A., Northway, M. J., Jayne, J. T., Aiken, A. C., Gonin, M., Fuhrer, K., Horvath, T., Docherty, K. S., Worsnop, D. R., and Jimenez, J. L.: Field-deployable, high-resolution, time-of-flight aerosol mass spectrometer, Anal. Chem., 78, 8281-8289, https://doi.org/10.1021/ac061249n, 2006.

Donahue, N. M., Robinson, A. L., Stanier, C. O., and Pandis, S. N.: Coupled partitioning, dilution, and chemical aging of semivolatile organics, Environ. Sci. Technol., 40, 2635-2643, https://doi.org/10.1021/es052297c, 2006.
Donahue, N. M., Epstein, S. A., Pandis, S. N., and Robinson, A. L.: A two-dimensional volatility basis set: 1. Organic-aerosol mixing thermodynamics, Atmos. Chem. Phys., 11, 3303-3318, https://doi.org/10.5194/acp-11-3303-2011, 2011.

Engelhart, G. J., Asa-Awuku, A., Nenes, A., and Pandis, S. N.: CCN activity and droplet growth kinetics of fresh and aged monoterpene secondary organic aerosol, Atmos. Chem. Phys., 8, 39373949, https://doi.org/10.5194/acp-8-3937-2008, 2008.

Frosch, M., Bilde, M., DeCarlo, P. F., Jurányi, Z., Tritscher, T., Dommen, J., Donahue, N. M., Gysel, M., Weingartner, E., and Baltensperger, U.: Relating cloud condensation nuclei activity and oxidation level of $\alpha$-pinene secondary organic aerosols, J. Geophys. Res., 116, D22212, https://doi.org/10.1029/2011JD016401, 2011.

Good, N., Topping, D. O., Allan, J. D., Flynn, M., Fuentes, E., Irwin, M., Williams, P. I., Coe, H., and McFiggans, G.: Consistency between parameterisations of aerosol hygroscopicity and CCN activity during the RHaMBLe discovery cruise, Atmos. Chem. Phys., 10, 3189-3203, https://doi.org/10.5194/acp10-3189-2010, 2010.

Hildebrandt Ruiz, L., Paciga, A. L., Cerully, K. M., Nenes, A., Donahue, N. M., and Pandis, S. N.: Formation and aging of secondary organic aerosol from toluene: Changes in chemical composition, volatility, and hygroscopicity, Atmos. Chem. Phys., 15, 83018313, https://doi.org/10.5194/acp-15-8301-2015, 2015.

Hong, J., Häkkinen, S. A. K., Paramonov, M., Äijälä, M., Hakala, J., Nieminen, T., Mikkilä, J., Prisle, N. L., Kulmala, M., Riipinen, I., Bilde, M., Kerminen, V.-M., and Petäjä, T.: Hygroscopicity, $\mathrm{CCN}$ and volatility properties of submicron atmospheric aerosol in a boreal forest environment during the summer of 2010, Atmos. Chem. Phys., 14, 4733-4748, https://doi.org/10.5194/acp14-4733-2014, 2014.

Huff Hartz, K. E., Rosenørn, T., Ferchak, S. R., Raymond, T. M., Bilde, M., Donahue, N. M., and Pandis, S. N.: Cloud condensation nuclei activation of monoterpene and sesquiterpene secondary organic aerosol, J. Geophys. Res., 110, D14208, https://doi.org/10.1029/2004JD005754, 2005.

Huffman, J. A., Docherty, K. S., Mohr, C., Cubison, M. J., Ulbrich, I. M., Ziemann, P. J., Onasch, T. J., and Jimenez, J. L.: Chemically-resolved volatility measurements of organic aerosol from different sources, Environ. Sci. Technol., 43, 5351-5357, https://doi.org/10.1021/es803539d, 2009.

IPCC: Summary for Policymakers, in: Climate Change 2013: The Physical Science Basis, Contribution of Working Group I to the Fifth Assessment Report of the Intergovernmental Panel on Climate Change, edited by: Stoker, T. F., Qin, D., Plattner, G.-K., Tignore, M., Allen, S. K., Boschung, J., Nauels, A., Xia, Y., and Midgley, P. M., Cambridge University Press, Cambridge, United Kingdom, and New York, NY, USA, https://doi.org/10.1017/CBO9781107415324, 2013.

Jimenez, J. L., Canagaratna, M. R., Donahue, N. M., Prevot, A. S. H., Zhang, Q., Kroll, J. H., DeCarlo, P. F., Allan, J. D., Coe, H., Ng, N. L., Aiken, A. C., Docherty, K. S., Ulbrich, I. M., Grieshop, A. P., Robinson, A. L., Duplissy, J., Smith, J. D., Wilson, K. R., Lanz, V. A., Hueglin, C., Sun., Y. L., Tian, J., Laaksonen, A., Raatikainen, T., Rautiainen, J., Vaattovaara, P., Ehn, M., Kulmala, M., Tomlinson, J. M., Collins, D. R., Cubison, M. J., Dunlea, E., J., Huffman, J. A., Onasch, T. B., Alfarra, M. R., Williams, P. I., Bower, K., Kondo, 
Y., Schneider, J., Drewnick, F., Borrmann, S., Weimer, S., Demerjian, K., Salcedo, D., Cottrell, L., Griffin, R., Takami, A., Miyoshi, T., Hatakeyama, S., Shimono, A., Sun, J. Y, Zhang, Y. M., Dzepina, K., Kimmel, J. R., Sueper, D., Jayne, J. T., Herndon, S. C., Trimborn, A. M., Williams, L. R., Wood, E. C., Middlebrook, A. M., Kolb, C. E., Baltensperger, U., and Worsnop, D. R.: Evolution of organic aerosols in the atmosphere, Science, 326, 1525-1529, https://doi.org/10.1126/science.1180353, 2009.

Jonsson, Å. M., Hallquist, M., and Saathoff, H.: Volatility of secondary organic aerosols from the ozone initiated oxidation of $\alpha$-pinene and limonene, J. Aerosol Sci., 38, 843-852, https://doi.org/10.1016/j.jaerosci.2007.06.008, 2007.

Karnezi, E., Riipinen, I., and Pandis, S. N.: Measuring the atmospheric organic aerosol volatility distribution: A theoretical analysis, Atmos. Meas. Tech., 7, 2953-2965, https://doi.org/10.5194/amt-7-2953-2014, 2014.

King, S. M., Rosenoern, T., Shilling, J. E., Chen, Q., and Martin, S. T.: Cloud condensation nucleus activity of secondary organic aerosol particles mixed with sulfate, Geophys. Res. Lett., 34, L24806, https://doi.org/10.1029/2007GL030390, 2007.

King, S. M., Rosenoern, T., Shilling, J. E., Chen, Q., and Martin, S. T.: Increased cloud activation potential of secondary organic aerosol for atmospheric mass loadings, Atmos. Chem. Phys., 9, 2959-2971, https://doi.org/10.5194/acp-9-2959-2009, 2009.

Kostenidou, E., Pathak, R. K., and Pandis, S. N.: An algorithm for the calculation of secondary organic aerosol density combining AMS and SMPS data, Aerosol Sci. Tech., 41, 1002-1010, https://doi.org/10.1080/02786820701666270, 2007.

Kostenidou, E., Lee, B. H., Engelhart, G. J., Pierce, J. R., and Pandis, S. N.: Mass spectra deconvolution of low, medium, and high volatility biogenic secondary organic aerosol, Environ. Sci. Technol., 43, 4884-4889, https://doi.org/10.1021/es803676g, 2009.

Kuwata, M., Chen, Q., and Martin, S. T.: Cloud condensation nuclei $(\mathrm{CCN})$ activity and oxygen-to-carbon elemental ratios following thermodenuder treatment of organic particles grown by $\alpha$ pinene ozonolysis, Phys. Chem. Chem. Phys., 13, 14571-14583, https://doi.org/10.1039/c1cp20253g, 2011.

Lee, B. H., Pierce, J. R., Engelhart, G. J., and Pandis, S. N.: Volatility of secondary organic aerosol from the ozonolysis of monoterpenes, Atmos. Environ. 45, 2443-2452, https://doi.org/10.1016/j.atmosenv.2011.02.004, 2011.

Massoli, P., Lambe, A. T., Ahern, A. T., Williams, L. R., Ehn, M., Mikkilä, J., Canagaratna, M. R., Brune, W. H., Onasch, T. B., Jayne, J. T., Petäjä, T., Kulmala, M., Laaksonen, A., Kolb, C. E., Davidovits, P., and Worsnop, D. R.: Relationship between aerosol oxidation level and hygroscopic properties of laboratory generated secondary organic aerosol (SOA) particles, Geophys. Res. Lett., 37, L24801, https://doi.org/10.1029/2010GL045258, 2010.

Moore, R. H., Nenes, A., and Medina, J.: Scanning mobility CCN analysis - A method for fast measurements of size-resolved CCN distributions and activation kinetics, Aerosol Sci. Tech., 44, 861871, https://doi.org/10.1080/02786826.2010.498715, 2010.

Murphy, D. M., Cziczo, D. J., Froyd, K. D., Hudson, P. K., Matthew, B. M., Middlebrook, A. M., Peltier, R. E., Sullivan, A., Thomson, D. S., and Weber, R. J.: Single-particle mass spectrometry of tropospheric aerosol particles, J. Geophys. Res., 111, D23S32, https://doi.org/10.1029/2006jd007340, 2006
Nakao, S.: Why would apparent $\kappa$ linearly change with $\mathrm{O} / \mathrm{C}$ ? Assessing the role of volatility, solubility, and surface activity of organic aerosols, Aerosol Sci. Tech., 51, 1377-1388, https://doi.org/10.1080/02786826.2017.1352082, 2017.

Paciga, A., Karnezi, E., Kostenidou, E., Hildebrandt, L., Psichoudaki, M., Engelhart, G. J., Lee, B.-H., Crippa, M., Prévôt, A. S. H., Baltensperger, U., and Pandis, S. N.: Volatility of organic aerosol and its components in the megacity of Paris, Atmos. Chem. Phys., 16, 2013-2023, https://doi.org/10.5194/acp16-2013-2016, 2016.

Pathak, R. K., Stanier, C. O., Donahue, N. M., and Pandis, S. N.: Ozonolysis of $\alpha$-pinene at atmospherically relevant concentrations: Temperature dependence of aerosol mass fractions (yields), J. Geophys. Res., 112, D03201, https://doi.org/10.1029/2006JD007436, 2007.

Petters, M. D. and Kreidenweis, S. M.: A single parameter representation of hygroscopic growth and cloud condensation nucleus activity, Atmos. Chem. Phys., 7, 1961-1971, https://doi.org/10.5194/acp-7-1961-2007, 2007.

Petters, M. D., Wex, H., Carrico, C. M., Hallbauer, E., Massling, A., McMeeking, G. R., Poulain, L., Wu, Z., and Stratmann, F.: Towards closing the gap between hygroscopic growth and activation for secondary organic aerosol - Part 2: Theoretical approaches, Atmos. Chem. Phys., 9, 3987-3997, https://doi.org/10.5194/acp-9-3999-2009, 2009.

Pope, C. A.: What do epidemiologic findings tell us about health effects of environmental aerosols?, J. Aerosol Med., 13, 335354, https://doi.org/10.1089/jam.2000.13.335, 2000.

Poulain, L., Wu, Z., Petters, M. D., and Wex, H.: Towards closing the gap between hygroscopic growth and $\mathrm{CCN}$ activation for secondary organic aerosols - Part 3: Influence of the chemical composition on the hygroscopic properties of volatile fractions of aerosols, Atmos. Chem. Phys., 10, 3775-3785, https://doi.org/10.5194/acp-10-3775-2010, 2010.

Prenni, A. J., Petters, M. D., Kreidenweis, S. M., DeMott, P. J., and Ziemann, P. J.: Cloud droplet activation of secondary organic aerosol, J. Geophys. Res., 112, D10223, https://doi.org/10.1029/2006JD007963, 2007.

Rickards, A. M. J., Miles, R. E. H., Davies, J. F., Marshall, F. H., and Reid, J. P.: Measurements of the sensitivity of aerosol hygroscopicity and the $\kappa$ parameter to the $\mathrm{O} / \mathrm{C}$ ratio, J. Phys. Chem., 117, 14120-14131, https://doi.org/10.1021/jp407991n, 2013.

Riipinen, I., Pierce, J. R., Donahue, N. M., and Pandis, S. N.: Equilibration time scales of organic aerosol inside thermodenuders: Evaporation kinetics versus thermodynamics, Atmos. Environ., 44, 597-607, https://doi.org/10.1016/j.atmosenv.2009.11.022, 2010.

Roberts, G. C. and Nenes, A.: A continuous-flow streamwise thermal-gradient $\mathrm{CCN}$ chamber for atmospheric measurements, Aerosol Sci. Tech., 39, 206-221, https://doi.org/10.1080/027868290913988, 2005.

Shilling, J. E., Chen, Q., and King, S. M.: Loading-dependent elemental composition of $\alpha$-pinene SOA particles. Atmos. Chem. Phys., 9, 771-782, https://doi.org/10.5194/acp-9-7712009, 2009.

Song, C., Zaveri, R. A., Alexander, M. L., Thornton, J. A., Madronich, S., Ortega, J. V., Zelenyuk, A., Yu, X.-Y., Laskin, A., and Maughan, D. A.: Effect of hydrophobic primary organic aerosols on secondary organic aerosol formation from 
ozonolysis of $\alpha$-pinene, Geophys. Res. Lett., 34, L20803, https://doi.org/10.1029/2007GL030720, 2007.

Stanier, C. O., Pathak, R. K., and Pandis, S. N.: Measurements of the volatility of aerosols from $\alpha$-pinene ozonolysis, Environ. Sci. Technol., 41, 2756-2763, https://doi.org/10.1021/es0519280, 2007.

Tritscher, T., Dommen, J., Decarlo, P. F., Gysel, M., Barmet, P. B., Praplan, A. P., Weingartner, E., Prévôt, A. S. H., Riipinen, I., Donahue, N. M., and Baltensperger, U.: Volatility and hygroscopicity of aging secondary organic aerosol in a smog chamber, Atmos. Chem. Phys., 11, 11477-11496, https://doi.org/10.5194/acp-11-11477-2011, 2011.

van Eeden, S. F., Yeung, A., Quinlam, K., and Hogg, J. C.: Systemic response to ambient particulate matter: Relevance to chronic obstructive pulmonary disease, Proc. Am. Thorac. Soc., 2, 61-67, https://doi.org/10.1513/pats.200406-035MS, 2005.

VanReken, T. M., Ng, N. L., Flagan, R. C., and Seinfeld, J. H.: Cloud condensation nucleus activation properties of biogenic secondary organic aerosol, J. Geophys. Res., 110, D07206, https://doi.org/10.1029/2004JD005465, 2005.
Wex, H., Petters, M. D., Carrico, C. M., Hallbauer, E., Massling, A., McMeeking, G. R., Poulain, L., Wu, Z., Kreidenweis, S. M., and Stratmann, F.: Towards closing the gap between hygroscopic growth and activation for secondary organic aerosol: Part $1-$ Evidence from measurements, Atmos. Chem. Phys., 9, 3987-3997, https://doi.org/10.5194/acp-9-3987-2009, 2009.

Zhang, Q., Jimenez, J. L., Canagaratna, M. R., Allan, J. D., Coe, H., Ulbrich, I., Alfarra, M. R., Takami, A., Middlebrook, A. M., Sun, Y. L., Dzepina, K., Dunlea, E., Docherty, K., DeCarlo, P. F., Salcedo, D., Onasch, T., Jayne, J. T., Miyoshi, T., Shimono, A., Hatakeyama, S., Takegawa, N., Kondo, Y., Schneider, J., Drewnick, F., Borrmann, S., Weimer, S., Demerjian, K., Williams, P., Bower, K., Bahreini, R., Cottrell, L., Griffin, R. J., Rautiainen, J., Sun, J. Y., Zhang, Y. M., and Worsnop, D. R.: Ubiquity and dominance of oxygenated species in organic aerosols in anthropogenically-influenced Northern Hemisphere midlatitudes, Geophys. Res. Lett., 34, L13801, https://doi.org/10.1029/2007GL029979, 2007. 